\title{
Resources, Attitudes and Strategies: Interest Group Participation in the Bork Confirmation Process
}

\section{Christine DeGregorio and Jack E. Rossotti, The American University}

With evidence from fifty nine organizations that worked to support or oppose the confirmation of Judge Robert H. Bork to the Supreme Court, we investigate how interest groups utilize their resources to influence politics. We assess the frequency with which advocacy groups adopt (1) an "inside the beltway" strategy, which involves their own members making direct appeals to officeholders; (2) an "outside the beltway" strategy, which involves enlisting the support of an unpredictable public through media campaigns; or (3) some combination of the two. We further develop and test a predictive model of the choice, allowing us to see the impact that the groups' resources and attitudes have on adopting one strategy or another. Among other things the findings help clarify the important role played by the mass public in Washington politics.

Such diverse scholars as James Madison (1961), E.E. Schattschneider (1960), and David Truman (1951) have written about the power of people who organize around a common political concern. Today, due to the advent of modern telecommunications and advanced market research, even unorganized individuals have unprecedented clout. That candidates for public office package their platforms and allocate their resources on the basis of their most recent-often daily-polling data is just one example of how modern information technologies provide new avenues of influence for mass opinion. While public opinion polls and focus groups have attracted considerable attention, little scholarship has been devoted to a second, now commonplace, avenue of influence in politics. When interest group leaders use advertisements and talk shows to reach beyond their membership to the general public, they are inviting those who are disengaged from policy making to have a say in tipping the balance of power on Capitol Hill. Not all groups within the pressure community reach out to the public, however, and it is our purpose to ask, "Why?"

This "outsider" strategy, as it is called, is only one means of securing the attention and possible cooperation of government officials. Mass media campaigns are particularly effective when they arouse strong public consensus. To arouse conflict can spell real trouble for organizers, who are

\footnotetext{
Christine Degregorio is an Assistant Professor in the School of Public Affairs at The American University.

JACK E. RossotTI is an Assistant Professor in the Washington Semester and World Capitols Program at The American University.
}

The American Review of Politics, Vol. 15, Spring. 1994: 1-19

${ }^{\circ} 1994$ The American Review of Politics 
trying to play down the controversy and to steer the decision makers to one particular course of action. The second approach, which advocacy groups apply quite successfully, is the direct, "insider" strategy. Here, the groups use professional lobbyists, staff and community leaders to button-hole government officials. While there is plenty of anecdotal evidence that interest groups use both the inside and the outside approaches (Bronner 1989, Schlozman and Tierney 1986, Smith 1988, Pertschuk and Schaetzel 1989), we have no empirical evidence on the precise breakdown. Nor do we know what factors come into play when groups endorse or abandon one or another approach. In the pages that follow we develop and test a predictive model of the choice, assuming that group leaders make efficient use of their organizations' resources to secure political advantage.

Explaining how and why groups behave as they do to influence governmental actions is satisfying on a number of levels. From a positive, scientific perspective we advance our understanding of the frequency and circumstances under which organized groups pressure public officials. From a normative point of view, the findings contribute evidence to the unsettled debate as to whether ours is a pluralist or an elitist society. For example, if the dominant strategy is to play the inside game of button-holing lawmakers, interest group leaders can be perceived as being party to an elitist style of power politics, which excludes ordinary people from having a say in the outcomes. If, in contrast, the issue leaders use their positions to inform and mobilize the unaffiliated masses, they promote a form of participatory governance in which political equality stems more from interest and ambition than from special contacts and position.

To analyze citizen involvement and interest group strategies, we use the controversy that ensued over President Ronald Reagan's nomination of Judge Robert H. Bork to the United States Supreme Court. The Bork case is particularly amenable to study because the players took unwavering positions either for or against the nominee, and they divided along what are traditionally regarded as conservative and liberal camps. Because they believed the decision would affect the judiciary for well over a generation, a large number of groups expended sizable amounts of money and time to influence the outcome. Moreover, they employed a wide range of tactics including: personal lobbying in the Senate, networking among members of grass-roots organizations, conducting media campaigns to reach the masses not affiliated with particular groups, and forming coalitions among likeminded participants to plan and coordinate the use of disparate resources.

For several reasons the findings from this single case cannot be construed to explain organizational strategies in the formulation of policy nor even in the confirmation of other justices to the Supreme Court. The 
brief time-frame for deliberation (i.e., four months), the clarity of the up or down vote, and the Senate's constitutional authority to confirm without interference from the House are just a few of the conditions that differentiate confirmatory politics from legislative politics. It is reasonable to expect that groups will deploy their resources differently when they are engaged in a protracted fight than when they see the end in sight. Moreover, there is no way of knowing how strategic choices are affected by opportunities for negotiation and compromise, available only in one of the two arenas.

The high-profile nature of Bork's campaign and the administration's initial passivity toward its nominee are two additional circumstances that merit attention. The near constant fascination that this decision held for the media, and through them the public, makes it impossible to know how the pressure community would respond if the public was not watching. Also, when members of the pressure community were gearing up to do battle over Bork, they found the administration to be remarkably passive. Whether due to overconfidence (McGuigan and Weyrich 1990), or fear that their involvement would serve as a lightning rod to the opposition (Bronner 1989), the President and his surrogates showed little enthusiasm for their nominee. They neither launched a media campaign nor did they make many visits to Capitol Hill.

This inactivity early in the process deprived the pro-Bork forces of the opportunity to sit back and free-ride on executive branch activities. They were on their own; they would have to build a coalition of support in the Senate without help from the President. While the administration's quiescence deprives us of the opportunity of observing the effects of executive action on interest group choices, the simplicity of the case offers us an opportunity to investigate interest group activity without the confounding effects (such as free-riding) that would have been induced by strong actions on the part of the executive branch.

As unique as it is, this case study into interest group strategies contains valuable lessons for practitioners in the business of advocacy, and for academics in the business of explaining political phenomena. We return to these considerations in the closing section of the article.

\section{The Context}

In the spring of 1987, immediately prior to Bork's nomination, the Supreme Court was almost evenly divided between liberal and conservative justices. When issues split the Court evenly it was typically Justice Lewis F. Powell Jr. who provided the decisive swing vote (Tribe 1985, Bronner 1989 and Pertschuk and Schaetzel 1989). This combination of political 
philosophies, together with the tendency of the Supreme Court to act in a judicially activist manner (Bronner 1989, O’Brien 1990), made for a politically explosive situation when Justice Powell submitted his resignation in June. McGuigan and Weyrich $(1990,3)$ aptly sum up the mood of the time:

In a flurry surrounding Powell's decision, political liberals began to fear the future of their agenda, which had been championed by an activist-dominated court since Earl Warren rose to Chief Justice on October 5, 1953 . . . On the other hand, strict constructionists-those who believe that judges should interpret the Constitution and not usurp legislative authority to make law-were ecstatic.

Liberals and conservatives alike viewed the appointment of Powell's replacement as one likely to have major ramifications on the subsequent decisions of the Court.

Great uncertainty plagued this confirmation, in part because the dynamics had changed in the Senate. The Republicans, having lost their majority in the 1986 elections, would have a confirmation fight like none experienced earlier in Reagan's tenure. ${ }^{1}$

Judge Bork's confirmation was made even more difficult in that, having come to the federal judicial system by way of academia, he left a paper-trail of opinion in his wake-a record that could be used by his opponents. His extensive and largely controversial opinions seemed to intensify the public's interest in the debate. Bork had repeatedly criticized the activism of the Supreme Court during the post-1954 period. He maintained that the Constitution should be interpreted according to the 'doctrine of original intent,' an orientation that would have largely curtailed the creation of many rights that were advanced by the Warren Court. Probably the most discussed of these was the right to privacy first enunciated in Griswold v. State of Connecticut, 381 U.S. 479 (1965) and later extended in Roe v. Wade, 410 U.S. 113 (1973) (Bork 1990). The controversy over privacy rights continues to dominate subsequent confirmations to the Supreme Court.

\section{Theory}

The method of appealing to members of Congress through their constituents is as old as the institution itself. Yet some changes occurred in the 1960s and 1970s that intensified the strategy of capturing the attention of congressmen through mass appeals (Berry 1989, Loomis and Cigler 1986, Schlozman and Tierney 1986, Kernell 1984, Ornstein and Elder 1978). Formerly, one only needed to advocate among a small coterie of party leaders and committee chairs. After the congressional reforms of the 1970s, including the increased dependence on staff, it became inefficient to appeal 
to officeholders one-on-one: there were too many individuals to reach, and coalitions were too fragile.

The three strategies-inside, outside and dual-approach successively broader audiences and exhaust successively larger expenditures of resources. The term "strategy" is used when several tactics are coupled together to suggest an overall approach. The inside method focuses on the senators and a small number of opinion leaders to whom they turn for advice. The tactics comprising this strategy include personal lobbying of senators, their staff and confidants, and testifying at hearings. The second sphere of communication encompasses all voting-aged citizens, even those beyond the established mailing lists of member-based interest groups. Letters-to-the-editor, appearances on talk shows, and paid advertisements are primarily directed outside the beltway to mobilize an attentive public who will prod senators to vote in line with the wishes of the opinion-shapers in their home states. Lastly, interest groups may prepare senators for public reaction in such a way as to reach, simultaneously, the decision makers and the citizens to whom the decision makers are accountable. This final, dual approach includes both of the other approaches and reaches the largest audience of all.

Assuming that conservatives want to succeed in seating Bork as much as liberals want to succeed in rejecting him, we do not expect the ideological position of an interest group to have a bearing on its choices over which strategy to pursue. Rather, as modeled below, the decision hinges on efficiency arguments exclusively. Resources matter because they constrain the choice set. Not all organizations have the wherewithal to launch a full array of power tactics. Attitudes enter the picture as well, but these are in terms of the judgments made by interest groups over what does and does not work, not whether the group is politically conservative or liberal.

The reasoning with respect to resources is straightforward. While it may be feasible for an interest group with meager resources to pursue the inside approach using only its staff and not its members, it would be very difficult to employ the most ambitious approach, the dual approach, without substantial shares of each. Whether paid professionals or volunteers, a core group of players is needed to assess which arguments will be persuasive with particular swing-vote senators and which communication techniques and messages will activate audiences from diverse regions of the country. ${ }^{2}$ In all cases, a group's effectiveness depends on its efficient use of resources.

Beyond having sizable differences in personnel and membership, organizations vary in their possession of another valuable resource-the extent to which they have easy access to members of the Senate and the media. Also, attitudes toward what works best in terms of influencing senators (efficacy) figure into the groups' choice of strategies. The group 
leaders, who believe senators are highly attentive to public opinion and constituent mail, for example, will be apt to embrace the outside approach of using mass campaigns. To carry out the strategy, however, they need receptive contacts in the media-editors and talk show hosts who will give their stories visibility. By way of contrast, the organizers will favor the inside approach when they believe that senators are primarily attentive to personal lobbying from interest group leaders and professional staff. This time, having an established network with well-placed senators and their aides will facilitate being called in to testify before the Senate Judiciary Committee and getting the attention of the key, swing-vote senators.

The hypothesized relationships are depicted in the following three statistical models:

MODEL 1:

Inside $=$ constant $+\mathrm{B}_{1}($ Staff $)+\mathrm{B}_{2}($ Senate $)+\mathrm{e}$

MODEL 2:

Outside $=$ constant $+\mathrm{B}_{1}($ Staff $)+\mathrm{B}_{2}($ Members $)+\mathrm{B}_{3}($ Media $)+\mathrm{e}$

MODEL 3:

Dual $=$ constant $+\mathrm{B}_{1}($ Staff $)+\mathrm{B}_{2}($ Members $)+\mathrm{B}_{3}($ Networks $)+\mathrm{e}$

where:

Inside, Outside, and Dual are dichotomous measures of the dependent variables. A value of one is assigned when the strategy was used and zero is assigned otherwise.

Staff and Members are interval measures of the number of individuals affiliated with the interest group. Staff are the salaried employees of the organization. Members are the voluntary, citizen corps that contribute varying amounts of time and money to the group's mission.

Senate and Media, in Model 1 and Model 2 respectively, are dichotomous variables. A "Senate" score of zero, for example, indicates that the interest group does not satisfy one or both of the following conditions: (1) known contacts with Senate insiders (officeholders and aides), and (2) the belief that senators respond better to professional lobbying than to constituent lobbying. A score of one indicates that the group possesses both these attributes. Similarly, a "media" score of zero indicates that the interest group lacks one or both of the ingredients, this time contacts with members of the media and the attitude that mass opinion has a substantial effect on senators' votes. A score of one indicates that the group meets both of these conditions. 
Networks also is dichotomous. This time, however, a value of one indicates that the organization has liaisons in place with members of both the Senate and the media, and a zero otherwise. As operationalized, the variable is only applicable in Model 3.

Because professional employees have skills that can be applied to any approach, Staff is expected to have a positive effect in all three models. The total number of members is omitted from Model 1 because all groups, even those without formal members, complement the lobbying efforts of their professional staff with credible representatives from impacted communities. Where one's volunteer base really counts is in applying the outside strategy. This is so because rank-and-file members are particularly adept at tailoring messages to inspire local audiences. The number of volunteers (Members) a group can engage to speak on talk shows, write letters-to-the-editor, and the like is expected to have a positive impact on the decision to use the outside strategy. Two final explanatory factors pertain to the combined effect of efficacy and infrastructure. The likelihood of choosing the inside approach increases when group leaders believe that senators are receptive to the personal appeals of professional lobbyists and they have the appropriate inside contacts to pull it off (Senate). In much the same way, the likelihood of choosing the outside approach increases when group leaders believe that senators are primarily attentive to the concerns of constituents and they have the contacts in the media (Media) to carry out the approach. Having networks (Networks) in both arenas contributes to the dual approach.

\section{Methodology}

Several scholars have documented the massive increase in and diversity among the groups organized to affect public policy. Foremost among them are Salisbury (1984 and 1986), Walker (1991, 1983) and Berry (1989). Anticipating a relationship between strategies and resources, we chose a sampling procedure that achieves maximum variation of the groups' access to resources.

The population frame included the names of 147 groups whose presence was previously documented in excellent case studies of the event (Bronner 1989, Pertschuk and Schaetzel 1989, McGuigan and Weyrich 1990). ${ }^{3}$ The anti-Bork organizations were stratified into two (small and large) categories, depending on the size of their staff (i.e., large groups equal or exceed the median reported number (35) of paid staff. ${ }^{4}$ A simple random sample of 25 groups then was drawn from each category. Due to its smaller size (53), the entire population of pro-Bork groups was approached. 
Seventeen of the sampled organizations disbanded, leaving no traceable spokesperson. We dismissed an additional ten groups because they limited their involvement in the controversy to an official endorsement for one side or the other; they invested no resources. With 78 percent of the remaining groups participating in the study, we obtain an array of organizations that is highly representative of the groups on the scene at the time (see Appendix A).

The respondents, all official personnel intimately familiar with their group's campaigns, addressed closed and open-ended questions paralleling our theoretical interests. Secondary data from the public record were used to validate the respondents' perceptions of their organizations' resources (staff and members) and activities (participation in public hearings and evidence of ads and editorials in the press). No substantial discrepancies resulted from the two perspectives, raising our confidence in the unverified responses pertaining to the participants' attitudes toward the efficacy of various influence approaches and their descriptions of the mix of strategies they employed.

While it would be parsimonious to examine how resources and attitudes affect one ordinal measure of the strategic alternatives that group leaders face, the inside, outside, and dual approaches do not lend themselves to such tidy analysis. The three-model approach, while ungainly in appearance, is methodologically conservative and theoretically sound. ${ }^{5}$

\section{Findings}

Before analyzing the activities adopted in this case, we examine general attitudes of efficacy and baseline resources that theoretically shape decisions over strategy. Two questions were used to assess the participants' attitudes toward different means of influencing votes in the Senate-contacting by constituents, not linked to an organized effort, and contacting by leaders and paid professionals with an interest group affiliation. ${ }^{6}$ In the first instance, 45.8 percent of the respondents consider that there is a "substantial" connection between the way senators vote and what they hear from the electorate. Thirty four percent hold the view that constituents have moderate influence, and 20 percent believe that constituents have little to no effect on senators' votes. $^{7}$

When asked to compare the value of the two approaches (organized professional lobbying versus constituent lobbying), 38 percent of the participants report seeing no difference. Twenty percent rate professional lobbying below constituent lobbying, and 42 percent rate it higher. ${ }^{8}$ No differences emerge when the attitudes toward the efficacy of alternative 
influence approaches are broken down by the stance one takes toward the confirmation. Where the groups differ, somewhat, is in terms of their resources (Table 1), tactics (Table 2) and strategies (Table 3 ) relevant to this case. The logit analysis used to estimate the effects of resources and attitudes on strategies follows an accounting of these baseline descriptive data.

At first glance, the evidence in Table 1 suggests that Bork's opponents were advantaged relative to his supporters. In only one instance, however, can we be confident that the observed disparity did not occur by chance (paid staff: $p=.06$ ). The other differences, even the two that suggest the supporting forces out-performed the opposing forces, are sufficiently unstable to raise caution. The subsequent models incorporate staff size and total membership size because these are the variables with the fewest missing observations.

Table 2 presents the frequencies with which the interest groups employed various tactics, distinguishing priority ${ }^{9}$ items from non-priority items for the opposing sides. The only items to attract a sizable amount of priority status are "lobbying senators" and "reaching out to grass-roots members." Notice that these tactics attract high scores regardless of one's attitudes toward the confirmation.

The groups engaged in several tactics to which respondents assign moderate importance. Reading Table 2 from top to bottom, these include "holding strategy sessions with senators or their staff," "preparing witnesses to testify at hearings," "reaching out to grass-roots," "coordinating internal group activities," "coordinating liaison activities with other groups," "holding group strategy sessions," and "networking with members of the media."

Two differences emerge within the tactics assigned mid-level priority. First, almost twice as many proponents as opponents of the confirmation place a medium rank on "writing opinion pieces" and "appearing on talk shows." Second, almost twice as many opponents as supporters place moderate priority on "holding strategy sessions with other groups." This latter observation squares with the accounts of the coalition activity of the two sides. The anti-Bork forces demonstrated more deliberate teamwork (Pertschuk and Schaetzel 1989, McGuigan and Weyrich 1990).

Respondents on both sides dismiss the value of expending resources on several items: "conducting research with which to understand Washington politics" and "preparing witnesses" are two examples. In the first case, most of the groups within the advocacy community report that they relied on one or two main sources for their information on the nominee's record. This explains why so few groups expended their own resources in this way. In the second case, there are two plausible explanations for why limited resources were allocated to preparing witnesses. First, interest groups rely 
Table 1. Profile of Resources by Position Toward the Bork Confirmation



on core members who are adept at the task, obviating the need for repeated briefings. A review of the public record confirms this fact; none of the witnesses were new to the congressional scene. Second, "As the (interest) groups ultimately understood, once Bork's own testimony was over, the case had been nearly decided" (Bronner 1989). The implication of this assertion is that the testimony of Judge Bork himself rendered other testimony largely unimportant to the outcome of the confirmation. 
Table 2. Assessments of Tactics Employed by Position Toward Bork Confirmation

(percentages in parentheses)

\begin{tabular}{|c|c|c|c|c|c|c|}
\hline Tactics & $\begin{array}{c}\text { Not } \\
\text { Employed }\end{array}$ & $\begin{array}{c}\text { PRO-BORK } \\
\text { Mid } \\
\text { Priority }\end{array}$ & $\begin{array}{l}\text { High } \\
\text { Priority }\end{array}$ & $\begin{array}{c}\text { Not } \\
\text { Employed }\end{array}$ & $\begin{array}{c}\text { ANTI-BORK } \\
\text { Mid } \\
\text { Priority }\end{array}$ & $\begin{array}{l}\text { High } \\
\text { Priority }\end{array}$ \\
\hline \multirow{4}{*}{$\begin{array}{l}\text { INSIDE-THE-BELTWAY } \\
\text { 1. Lobbying the Senate } \\
\text { 2. Participating in strategy sessions } \\
\text { with Senators or staff } \\
\text { 3. Conducting polls or other research } \\
\text { on politics in D.C. } \\
\text { 4. Preparing witnesses }\end{array}$} & & & & & & \\
\hline & $10(34.5)$ & $8(27.6)$ & $11(37.9)$ & $5(16.7)$ & $9(30.0)$ & $16(53.3)$ \\
\hline & $15(51.7)$ & $14(48.3)$ & $0(0.0)$ & $14(46.7)$ & $15(50.0)$ & $1(3.3)$ \\
\hline & $17(58.6)$ & $10(34.5)$ & $2(6.9)$ & $21(70.0)$ & $9(30.0)$ & $0(0.0)$ \\
\hline \multirow{3}{*}{$\begin{array}{l}\text { OUTSIDE-THE-BELTWAY } \\
\text { 1. Reaching out to group members } \\
\text { 2. Writing op-ed pieces, appearing } \\
\text { on talk shows, etc. } \\
\text { 3. Paying for promotional ads } \\
\text { 4. Conducting polls or other research } \\
\text { toward building mass appeal }\end{array}$} & & & & & & \\
\hline & $4(13.8)$ & $14(48.3)$ & $11(37.9)$ & $4(13.3)$ & $12(40.0)$ & $14(46.7)$ \\
\hline & $13(44.8)$ & $14(48.3)$ & $2(6.9)$ & $19(63.3)$ & $8(26.7)$ & $3(10.0)$ \\
\hline 1. Coordinating internal group & $6(20.7)$ & $17(58.6)$ & $6(20.7)$ & $9(30.0)$ & $14(46.7)$ & $7(23.3)$ \\
\hline $\begin{array}{l}\text { 2. Coordinating activities with other groups } \\
\text { 3. Holding strategy sessions for groups }\end{array}$ & $6(20.7)$ & $20(69.0)$ & $3(10.3)$ & $9(30.0)$ & $19(63.3)$ & $2(6.7)$ \\
\hline (own and others) & $15(51.7)$ & $11(37.9)$ & $3(10.3)$ & $6(20.0)$ & $21(70.0)$ & $3(10.0)$ \\
\hline 4. Networking to keep presence in media & $11(37.9)$ & $12(41.4)$ & $6(20.7)$ & $13(43.3)$ & $15(50.0)$ & $2(6.7)$ \\
\hline$N=59$ & & & & & & \\
\hline
\end{tabular}


In the "not employed" column there are two additional differences to note. The $\mathrm{N}$ of pro-Bork groups that did not employ "lobbying senators" and "holding strategy sessions with other groups" was twice as great as the $\mathrm{N}$ of anti-Bork groups that eschewed these tactics.

In Table 2 the tactics are grouped to include substantively different behaviors: "inside the beltway," "outside the beltway," and "maintenance." 10 This grouping was not apparent to the participants when they completed the interview. Once the participants reacted to the listed items, however, the interviewer acknowledged the conceptual distinction with a follow-up probe: "Examining the activities that your group concentrated on, it looks like you employed an 'inside the beltway,' 'outside the beltway' or 'dual' strategy." The interviewer filled in the ending and asked the respondent for confirmation of this assessment. The breakdown of strategies is presented in Table 3.

\section{Table 3. Overall Strategy by Position Toward Bork Confirmation} (percentages in parentheses)

\begin{tabular}{lrr}
\hline Strategy & Pro-Bork & Anti-Bork \\
\hline Inside-the-beltway & $9(31.0)$ & $5(17.9)$ \\
Outside-the-beltway & $9(31.0)$ & $5(17.9)$ \\
Dual & $11(37.9)$ & $18(64.3)$ \\
$\mathrm{N}=57$ & & \\
\hline
\end{tabular}

Notice here that while the pro-Bork forces exhibit roughly equivalent levels of the three strategies-inside, outside and dual, the anti-Bork forces do not. Two thirds of these groups report using a dual strategy to sabotage the confirmation. We expect that disparities in organizational wealth and feelings of efficacy explain the difference, and proceed with the analysis. For two reasons Table 4 does not include the groups' stance toward Bork. First, when included as a control variable 'side' has little to no substantive effect on strategy. Second, owing to the additional degree of freedom, the performance of all three models improves. The parameter estimates are stable, unchanged in direction and magnitude, and more precise.

First, in Table 4 we see that all the signs on the estimated coefficients are positive, as predicted. Second, with the confidence tests as a guide we can be somewhat sure that at one time or another all but one of the explanatory variables (members) are important predictors of interest group strategies. Third, the model chi-squares and accompanying probabilities indicate 


\section{Table 4. The Effects of Resources and Attitudes ${ }^{a}$ on Interest Group Strategies}

(standard errors in parentheses)

\begin{tabular}{|c|c|c|c|}
\hline Variable & (Model 1) & $\begin{array}{l}\text { Outside } \\
\text { (Model 2) }\end{array}$ & $\begin{array}{c}\text { Dual } \\
\text { (Model 3) }\end{array}$ \\
\hline Constant & $-0.405(.418)$ & $0.776(.424) * *$ & $0.922(.450)^{* * *}$ \\
\hline Staff & $0.031(.023)^{*}$ & $0.006(.008)$ & $0.014(.009)^{* *}$ \\
\hline Members & - & $0.000(.000)$ & $0.001(.000)$ \\
\hline Networks & - & - & $1.074(.649)^{* *}$ \\
\hline Senate & $1.080(.846)^{*}$ & - & - \\
\hline Media & - & $1.300(1.11)$ & - \\
\hline $\begin{array}{l}\text { Model Chi-square } \\
N=50\end{array}$ & $\begin{array}{l}7.03 \text { with } 2 \text { d.f. } \\
(p=0.030)\end{array}$ & $\begin{array}{l}2.19 \text { with } 3 \text { d.f. } \\
\quad(p=0.533)\end{array}$ & $\begin{array}{l}8.81 \text { with } 3 \text { d.f. } \\
\quad(p=0.030)\end{array}$ \\
\hline \multicolumn{4}{|c|}{ NOTE: The table reports the results of logit equations. See the text for descriptions of the variables. } \\
\hline \multicolumn{4}{|c|}{$\begin{array}{l}\text { "Three of the dichotomous explanatory variables equal " } 1 \text { " if and only if interest group participants } \\
\text { report having (1) established contacts in the Senate, or in the media, or in both the Senate and the } \\
\text { media (networks), and (2) higher than average levels of confidence in the efficacy of lobbying } \\
\text { Senators through direct professional contacts (in the case of Senate), through indirect means via the } \\
\text { mass public (in the case of media), or both avenues of influence (in the case of networks). The } \\
\text { number of staff and members are interval measures reported in the Encyclopedia of Associations } \\
\text { and confirmed upon interview. }\end{array}$} \\
\hline
\end{tabular}

that more guesswork remains in explaining the decision to take an outside approach than either of the other two choices. We speculate on the meaning of this in the concluding section.

For a substantive interpretation of the results we estimate the probability of choosing each strategy at below average, average, and above average levels of resources. ${ }^{11}$ Estimates of the probability of adopting one or another strategy with mean levels of resources across the board establishes a baseline. Here the advocacy groups are most likely $(.84)$ to adopt an inside approach, second most likely to use an outside approach (.77), and least likely to adopt a dual approach (.51). Given the effort it takes to reach successively larger audiences, it is reasonable that the probabilities associated with these strategies diminish as they do. 
When all explanatory variables are allowed simultaneously to increase and then simultaneously to decrease we derive predicted values of a prototypically "rich" organization and a prototypically "poor" organization. Wellendowed organizations with resources at one standard deviation above the mean are almost as likely to employ the inside strategy (.98) as the outside strategy (.93). When resources are abundant, even employing the dual strategy is quite likely (.86), albeit less likely than focusing on a single strategy. A somewhat different scenario occurs when comparing the estimated behaviors of resource-poor organizations. Here the likelihood of choosing the inside or the dual approach drop to 60 percent and 28 percent, respectively. While the likelihood of going public decreases, it only decreases to 68 percent, emerging as the strategy of choice when resources and feelings of efficacy are at their nadir. Apparently, it is easier for interest groups to reach the media and have opinion pieces published or to participate on talk shows than it is to reach members of the Senate and their staff when resources are low.

What do we learn from this glimpse into the relationships among attitudes, resources and the strategic choices of interest groups? First, the decision to specialize and adopt an outside strategy rests not so much on one's access to members and staff as it rests on nurturing relations within the media. Indeed the only strategy that membership size affects is the most ambitious one, the dual approach.

There are at least two interpretations of this result. First, scholarly and journalistic accounts are replete with stories of the personal side of power (Smith 1988, Matthews 1988, Weatherford 1985). Elected officials and their staffers often reach out to lobbyists for needed information. The choice of lobbyist turns on such attributes as trust and credibility. For small, poorly endowed organizations this is a promising result. Abundant resources are not a necessary precondition for becoming a power broker on Capitol Hill. Any group can cultivate a network, develop credibility and play a part in Washington politics.

Second, the negative finding about membership size is not startling when one considers what interest group scholars have been reporting for decades (Olson 1965, Wilson 1973). Individuals join groups for a variety of reasons, oftentimes having little to do with the organization's mission. The few attentive members who constrain management's choices of staff and leaders do so only when such choices pose a risk to the cause. The statistical insignificance of the membership base may be due, therefore, to a calculation among members that allocating resources at this level-going inside or outside-has little associated risk. In a different political battle this may not be the case. 
Furthermore, while the evidence suggests that member volunteers are passive when it comes to allocating resources among approaches, we have no reason to believe that members' preferences do not critically shape the mix of activities within a particular strategy - the timing and focus of one's lobbying efforts, for example. This question pertains to choices over tactics and is beyond the scope of our inquiry.

Beyond bringing into sharp relief the importance of political networking, these findings renew confidence in the importance of professional staff. Staff size makes a substantial difference in two out of the three strategic choices that interest groups face-the decision to specialize in the insider game and the decision to diversify and employ both strategies at once.

\section{Summary and Implications}

The struggle surrounding the confirmation of Judge Bork presents an excellent setting in which to compare the attitudes, resources and performance of the organizations within this interest group community. We make no generalizations to other groups or other events. The evidence from the Bork example, however, enlightens us about the role the mass public plays in political struggles among interest groups.

When a conceptual distinction is made between the way pressure tactics are bundled into overall strategies-inside, outside and dual-we document that the distinction is real and quantify the mix more precisely than heretofore. Not surprisingly, the probabilities of mounting an inside (.84), outside (.77), or dual (.51) strategy correspond nicely with our earlier theoretical discussion about the costliness of reaching out to successively larger audiences. Indeed, a naive observer might guess that an advocacy group is more likely to lobby senators and testify at hearings than to go public with media campaigns, regardless of circumstance. This is not the case, however. When we compare organizations of greater and lesser means, we find that the public strategy is the most stable of the three. A drop in resources reveals a precipitous drop of over 20 percent in the probability a group will adopt the dual or the inside strategy. While the loss of resources also tends to depress the likelihood that a group will take the outside approach, the effects are muted. This is good news for advocates of pluralist democracy. Group leaders are not quick to disregard involving the unaffiliated masses. Finally, when we artificially increase organizational riches one standard deviation above the mean, all three strategies receive a boost in the likelihood of their adoption.

We test three models, which are theoretically comparable, to analyze the independent effects combinations of resources and attitudes have on the 
groups' strategic decisions. The evidence allows us to be most confident about the impacts having established rapport with members of the Senate and the media have on adopting an inside and outside strategy, respectively. Staff size matters in two instances-in the decision to focus on the senators and their confidants (inside influence) and the decision to cover all one's bases and adopt the dual approach. And under no circumstance does the size of the membership matter in shaping the groups' overall approach. Further research that focuses on the motives of members rather than their numbers would provide an interesting subsequent test of this relationship between members and strategies.

Based on the performance of the models, we are the farthest from "explaining" the outside approach. One reason for this may be the risks that are associated with going public. Compared to its counterpart the outside strategy is fraught with uncertainties. First, mass appeals are not useful unless the issue under consideration arouses public interest. Second, some salient issues are controversial. Since it is extremely difficult to control the reactions of the mass electorate once an advertisement has run or the viewers of "Nightline" have tuned out, leaders of advocacy groups must assess the likelihood that a highly visible, public campaign will have the desired effect. In contrast, the inside approach is comparatively safe. When lobbying a handful of senators who represent the swing-vote, for example, the lobbyists can do their homework, personalize their appeals and minimize the risk of increasing resistance to their cause.

The Bork case was both salient and rife with conflict. As a result, these findings provide no insight on what happens when either or both of these conditions are absent. To measure the effects of issue salience and conflict on strategic choices, we need to compare interest group behavior across diverse issues. Two recent presidential nominations provide an opportunity for testing the effects of salience. The selection of Robert M. Gates to head up the Central Intelligence Agency created a flap that extended only as far as the Washington beltway, while the debate over adding Judge Clarence Thomas to the Supreme Court created considerable controversy in far-flung regions of the country. Expanding the inquiry to include such cases that arouse a spectrum of public interest would extend the work of Denzau and Munger (1986), Wilson (1973) and others on the part that public attentiveness plays in the internal dynamics of group decision making. The complete story awaits repeated and subsequent systematic inquiry. 


\section{NOTES}

The authors want to thank Michael Koeppel for his valuable assistance throughout this endeavor. Also, Laura Langbein provided helpful feedback on an earlier version of this manuscript.

${ }^{1}$ Justice Sandra Day O'Connor was confirmed by a vote of 99-0 (1981); Justice William Rehnquist was elevated to Chief Justice by a vote of 65-33 (1986); Justice Antonin Scalia was confirmed by a margin of 98-0 (1986).

${ }^{2}$ The model allows a role for what are essentially paper organizations in which one individual with sufficient capital could engage in any one of the three strategies outlined thus far.

${ }^{3}$ In addition, we acknowledge the valuable assistance of Nancy Broff (Alliance for Justice), Daniel Casey (American Conservative Union), and Patrick McGuigan (Coalitions for America). With their help we were able to fill gaps in the population frame and locate several interviewees who were actively involved.

${ }^{4}$ In a few cases staff data were unavailable in the Encyclopedia of Associations (1990). When this occurred we relied on other measures of organization size (i.e., membership and budgets).

${ }^{5}$ Using one multinomial logit equation necessitates that the values of the dependent variable can be arranged in ascending order. The only distinction that is truly ordinal here, however, is the difference between using one approach and using two approaches at once. In other respects these strategies are qualitatively different, with no clear measure as to the size of their difference (e.g., one approach applies pressure directly on the Senate insiders, while the other approach applies pressure to senators indirectly through their constituents in the mass public).

"In subsequent analysis, the high scores on these two questions are coded " 1 " for their positive attitude toward the efficacy of (1) contacts from the mass electorate (a component of the media variable) and (2) contacts from paid staff (a component of the Senate variable).

${ }^{7}$ The question was, "From your experience in advocacy work, generally, do you think senators' votes are infuenced 'little,' 'moderately,' or 'substantially' by what they hear from the American electorate (i.e., constituents and voters not formally organized)?"

${ }^{8}$ The question was, "Is professional lobbying (i.e., by paid staff and opinion leaders from organized groups) __ less, ___ equal, or ___ more important than constituency lobbying?"

${ }^{9}$ Out of the twelve listed activities, respondents selected and ranked four items 'one' through 'four' in order of the intensity with which they were employed. The items that were ranked 'one' and 'two' are included in the high priority columns. The items that were ranked 'three' and 'four' and 'used' but without rank are included in the 'mid-priority' column.

${ }^{10} \mathrm{Although}$ group maintenance is not a focus of this study, the data support the previous findings of many scholars (e.g., Olson 1965, Salishury 1969, Walker 1983). To survive organizationally, interest groups persistently devote resources to sustain willingness among members and to make tough choices with respect to policy.

${ }^{11}$ These calculations are based on the formula in Hanushek \& Jackson $(1977,201)$ that transforms maximum likelihood estimators into values of the dependent variable. 


\section{APPENDIX A \\ Sample of Interest Groups}

PRO-BORK

Ad Hoc Committee in Defense of Life

American Conservative Union

American Farm Bureau Federation

Americans for Tax Reform

American Legislative Exchange Council

Center for Judicial Studies

Christian Action Council

Christian Voice

Coalitions for America

College Republican National Committee

Concerned Women for America

Conservative Leadership PAC

Council for National Policy, Inc.

(CNP, Inc.)

Federal Criminal Investigators'

Association

Fraternal Order of Police

Free the Court

International Association of

Chiefs of Police

International Narcotics Enforcement

Association

Moral Majority

National District Attorneys' Associations

National Jewish Coalition

National Law Enforcement Council

National Republican Heritage Group's

Council

National Sheriff' Association

National Troopers' Association

Renaissance Women

Victims Assistance Legal Organization

We the People
ANTI-BORK

Alliance for Justice

American Civil Liberties Union

American Federation of State,

County, and Municipal Employees

Americans for Religious Liberty

Center for Population Options

Citizen Action

Communications Workers of America

Epilepsy Foundation of America

Federally Employed Women

Federation of Women Lawyers

Friends of the Earth

International Association of Machinists

Mexican-American Women's National

Association

National Abortion Rights Action League

National Coalition to Abolish the Death Penalty

National Conference of Women's Bar Associations

National Gay and Lesbian Task Force

National Lawyer's Guild

National Women's Health Network

National Association of Social Workers

National Council of La Raza

National Urban League

9 to 5, National Association of Working Women

People for the American Way

Rainbow Lobby

Sane/Freeze

Sierra Club

United States Student Association

YWCA/USA

NotE: Two names have been omitted in deference to the respondents' requests for complete anonymity. 


\section{REFERENCES}

Berry, Jeffrey M. 1989. The Interest Group Society, second edition. Boston: Little, Brown \& Co.

Bronner, Ethan. 1989. Battle for Justice: How the Bork Nomination Shook America. New York: W.W. Norton \& Co.

Bork. Robert H. 1990. The Tempting of America: The Political Seduction of the Law. New York: The Erie Press.

Burek. Deborah M.. Karen E. Kolk. and Annette Novallo, eds. 1990. Encyclopedia of Associations, 2nd ed. Detroit: Gale Research, Inc.

Denzau, Arthur T. and Michael C. Munger. 1986. Legislators and Interest Groups: How Organized Interests Get Represented. American Political Science Review 80: 90-106.

Hanushek, Eric and John Jackson. 1977. Statistical Methods for Social Scientists. New York: Academic Press.

Kernell, Samuel. 1986. Going Public: New Strategies of Presidential Leadership. Washington, DC: Congressional Quarterly Press.

Loomis, Burdett A. and Allan J. Cigler. 1986. Introduction: The Changing Nature of Interest Group Politics. In Allan J. Cigler and Burdett Loomis, eds., Interest Group Politics. Washington. DC: Congressional Quarterly Press.

Madison. James. 1961. The Federalist. New York: New American Library.

Matthews, Christopher J. 1988. Hardball. New York: Harper and Row.

McGuigan, Patrick and Dawn H. Weyrich. 1990. Ninth Justice: The Fight for Bork. Lanham, MD: University Press of America.

Olson. Mancur Jr. 1965. The Logic of Collective Action. New York: Schocken.

O'Brien. David M. 1990. Storm Center: The Supreme Court in American Politics, second ed. New York: W.W. Norton and Company, Inc.

Ornstein, Norman and Shirley Elder. 1978. Interest Groups, Lobbying and Policymaking. Washington, DC: Congressional Quarterly Press.

Pertschuk, Michael and Wendy Schaetzel. 1989. The People Rising: The Campaign Against the Bork Nomination. New York: Thunder's Mouth Press.

Salisbury, Robert H. 1986. Washington Lobbyists. In Allan J. Cigler and Burdett Loomis, eds., Interest Group Politics. Washington, DC: Congressional Quarterly Press. 1984. Interest Representation: The Dominance of Institutions. American Political Science Review 78: 64-74. 8: $1-32$.

1969. An Exchange Theory of Interest Groups. Midwest Journal of Political Science

Schattschneider, E.E. 1960. The Semisovereign People. New York: Holt, Rinehart and Winston.

Schlozman, Kay Lehman and Tierney. John T. 1986. Organized Interests and American Democracy. New York: Harper and Row.

Smith. Hedrick. 1988. The Power Game: How Washington Works. New York: Ballantine Books.

Tribe, Lawrence H. 1985. God Save This Honorable Court. New York: Random House.

Truman. David. 1951. The Governmental Process. New York: Knopf.

Walker, Jack L. 1991. Mobilizing Interest Groups in America. Ann Arbor: The University of Michigan Press.

1983. The Origins and Maintenance of Interest Groups in America. American Political Science Review 77: 390-406.

Weatherford, J. Mclver. 1985. Tribes on the Hill. Granby, MA: Bergin and Garvey Publishers.

Wilson, James Q. 1973. Political Organizations. New York: Basic Books, Inc. 